\title{
Brevity is the soul of advocacy, experts say
}

K eep it simple, stupid." That's the advice a panel of public relations experts gave delegates to the Canadian Medical Association's 144th annual general meeting in St. John's, Newfoundland and Labrador during a strategic session on how to influence politicians, the media and patients to transform the health care system.

Simple, specific and consistent demands, as well as strong relationships with patients and policy-makers, are the foundations of effective advocacy, but too often physicians forget these fundamentals in flogging health care transformation, the panel told delegates Aug. 23.

"They come to a meeting or an organization with too long a shopping list of demands that would require changes not just to the health system, but the immigration system, the copyright system, the university system, research funding and pay schedules. And, for politicians, it's overwhelming," says panelist and former cabinet minister Chuck Strahl. "Not only that, but they assume a degree of sophistication on the part of political folks when, in general, they're generalists. The average politician has a thousand things they've got to know a little about, so you can't assume they understand how the local hospital board works."

Politicians are used to dealing with the "capstone" of a pyramid of information - one issue and one solution on one piece of paper, explains Strahl. "But if I went around [General Council] with a microphone and asked everyone to give me a snapshot, they would ramble on for about two minutes. I fear if the CMA doesn't boil it down to the phrase that pays, then what's their chances of getting transformation on the news tonight?"

Short, sweet sound bites and specific, practical solutions are the name of the game, panelist and former Member of Parliament Dr. Keith Martin earlier told delegates. "Fear dominates the environment when you talk about

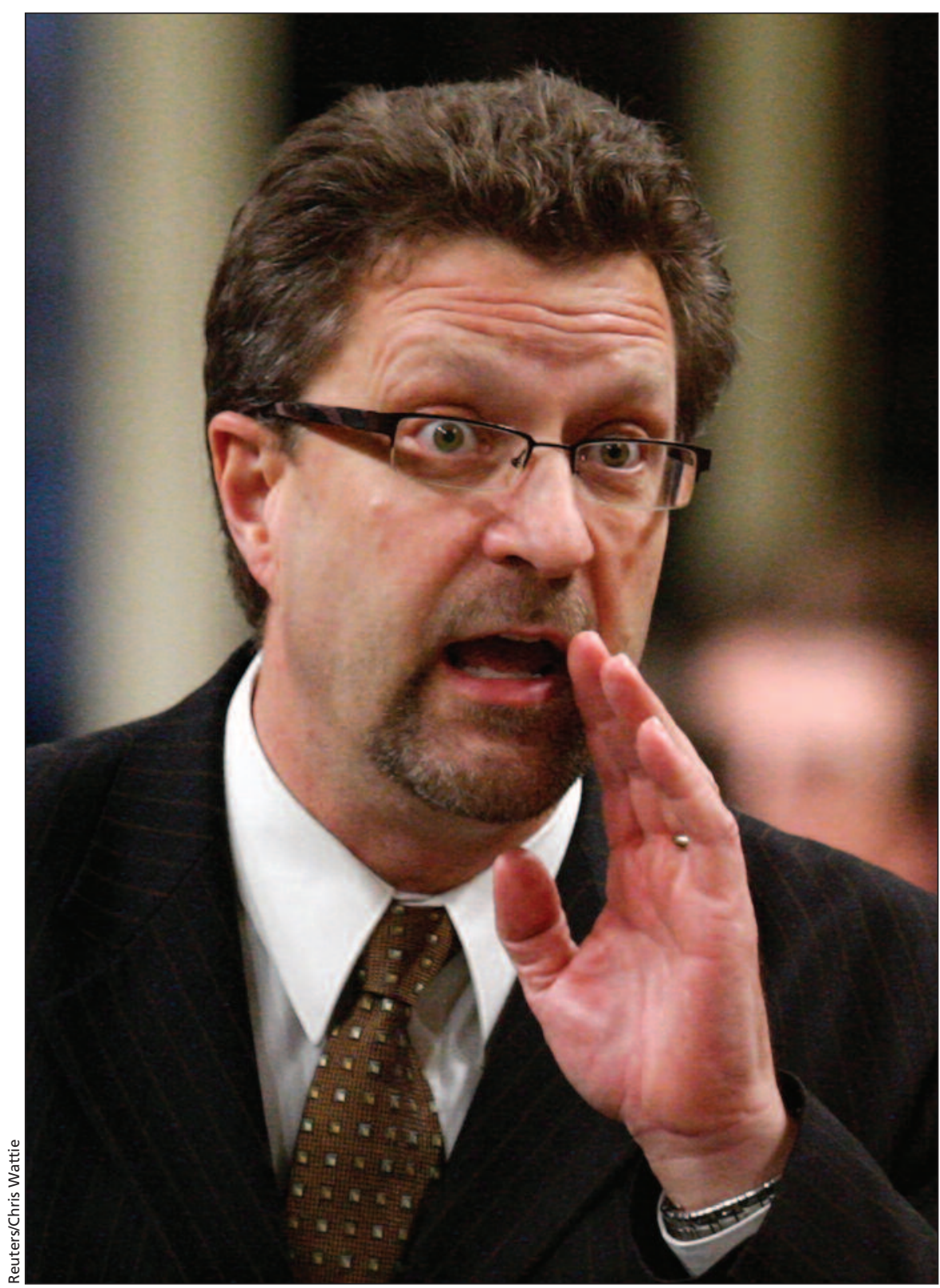

Former Conservative cabinet minister Chuck Strahl says medical advocacy groups should not assume "a degree of sophistication on the part of political folks."

health care beyond embracing the Canada Health Act," and physicians shouldn't expect politicians to forge ahead without a clear map of their next steps, he explained.

"Politicians wrap themselves in the Canada Health Act," Strahl earlier told delegates. "It's the refuge of cowards," so physicians must be prepared to appeal for transformation on whatever grounds they can.

"Look through the rest of the agenda, tell them how it can help the economy, read them back their own words and say here's how we can help you do that," he explained. "You'll be surprised how many ministers will respond." 
There's strength in numbers, so physicians should aim to build partnerships with patients, other health professionals and advocacy groups, Martin said. "The larger the voice with a consistent message, the safer the government will feel to act."

It's also important to build relationships with key politicians, in good times and bad, Strahl explained. "If a good thing happens, you've got to be there. Blow some smoke up their wazoos, lend your voice to the right issues and when you go to the podium, don't kick them between the pockets, but use the occasion to say this is a good thing, and here are three more good things we can do."

Political engagement doesn't require physicians to be involved in any one party, but it does mean being available, Deb Maskens, panelist and founder of Kidney Cancer Canada, told delegates. "It's not enough for you to vent your frustrations within the confines of your offices with the doors closed."

Physicians should be prepared to listen to patients, write letters on their behalf, meet with government or give a quote to the media, she added. "There's not one formula that's going to get the message across but we cannot stay silent." — Lauren Vogel, CMAJ

CMAJ 2011. DOI:10.1503/cmaj.109-3984 